\title{
Tietotekniikan vastuuhenkilöitä koulutettiin monimuoto-opetuksen avulla
}

\author{
Kokemuksia Lapin LAIKO-kokeilusta
}

Tietotekniikan oppimista monimuoto-opetuksen keinoin kokeiltiin kahden vuoden ajan Lapin läänissä, missä etäisyydet kiinteään opetuspaikkaan ovat pitkät. Kokeilulla haluttiin mm. tietoa siitä, miten pitkäjänteinen tietotekniikan opiskelu soveltuu suoritettavaksi työn ohessa ja monimuoto-opetuksen mahdollisuuksia hyväksi käyttäen.

Työskentelumuotoja oli paljon: lähiopetusta, puhelinluentoja, päätekeskusteluja, sähköpostin ja telekopion hyödyntämistä, videoneuvotteluja ja harjoitustöitä kunkin omalla työpaikalla. Siitä, mikä kokeilussa kangersi ja mikä luisti, kertoo seuraavassa Tornion liiketalouden ja tietotekniikan instituutin lehtori Eliisa Hacklin. "Negatiivisetkaan kokemukset eivät välttämättä merkitse, että jokin menetelmä ei sovellu aikuisten monimuotoopetukseen", toteaa kirjoittaja.

Lapin läänissä käynnistyi vuonna 1986 aikuiskoulutuskokeilu LAIKO, jonka tavoitteena oli etsiä uusia koulutusratkaisuja. Laiko sisältää joukon koulutuskokeiluja, joita toteutetaan eri puolilla Lappia useissa oppilaitoksissa. Kokeilun tuloksia on esitelty jo aiemminkin tässä lehdessä.

Tässä kirjoituksessa esitellään Tornion liiketalouden ja tietotekniikan instituutissa 4.11.1986-28.10.1988 toteutettua atk-vastuuhenkilökoulutuksen kokeilua. Tänä aikana instituutti järjesti kaksi täydennyskoulutuskurssia pituudeltaan 600-700 tuntia. Koulutukseen osallistui 41 opiskelijaa lappilaisista pienyrityksistä ja julkishallinnosta.
Koulutus toteutettiin Laikon kokeilumäärärahan ja Lapin läänin kehittämisrahan turvin. Taustalla oli huoli lappilaisten pysymisestä mukana tietotekniikan kehityksessä.

\section{Kokeilun tavoitteet}

Mitä atk-vastuuhenkilö tekee? Työpaikallaan hän osallistuu tietojärjestelmän rakentamiseen, hankintaan ja käyttöönottoon. Hän kehittää tietojärjestelmää ja toimii yhdyshenkilönä atk-palvelujen ja muiden toimintojen välillä. Kokeilun yleistavoitteena olikin selvittää, miten pitkäjänteinen tietotekniikan opetus soveltuu työn ohessa suoritettavaksi mo- 
nimuoto-opetuksen menetelmiä hyväksi käyttäen.

Koulutuksessa kokeiltiin erityisesti puhelinneuvottelun, telekopiolaitteen, mikrotietokoneiden, videon, videotekstin, päätepostin ja päätepuhelimen soveltuvuutta monimuoto-opetukseen.

Kokeilussa haluttiin myös tietoa siitä, miten etäopetuksen menetelmät toimivat käy. tännössä, miten opetusjärjestelyt vaikuttavat koulutukseen hakeutumiseen, miten opiskelijat menestyvät ja mitä kaikki maksaa.

Opetussuunnitelman kannalta oli selvitettävä, millaista tietotekniikan osaamista työe. lämä edellyttää, miten otetaan huomioon opiskelijoiden yksilölliset tarpeet ja aiemmat opinnot sekä miten kurssi vaikuttaa opiskelijoiden urakehitykseen. Opettajilla ei ollut kokemuksia monimuoto-opetuksesta; heiltä samoin kuin opiskelijoiltakin haluttiin palautetta toiminnan onnistumisesta.

\section{Monimuoto-opetus}

Monimuoto-opetuksen termi lienee vakiintunut kieleemme tällä vuosikymmenellä (Monimuoto-opetuksen työryhmän muistio, 1986). Atk-vastuuhenkilökoulutuksessa monimuoto-opetuksen peruselementit olivat lähiopetus, etäopetus ja opetuksen kytkeminen työhön.

Lähiopetus tarkoittaa seminaaripäiviä, jolloin kaikki opiskelijat kokoontuivat yhteen. Lähiopetusjaksoja järjestettiin koulutuksen alussa ja sen jälkeen $1-1,5$ kuukauden vä. lein. Niiden tehtävänä oli aluksi tutustuttaa koulutettavat ja kouluttajat toisiinsa sekä motivoida ja orientoida opiskeluun. Myöhem. min lähiopetuspäivillä opetettiin sellaisia asioita, joita olisi ollut vaikeaa tai mahdotonta käsitellä etäopetuksena. Tällaisina aiheina mainittakoon esimerkiksi Venturajulkaisujärjestelmä ja seinätekniikka tietojärjestelmän suunnittelussa.

\section{MONIMUIOTO-OPETUS}

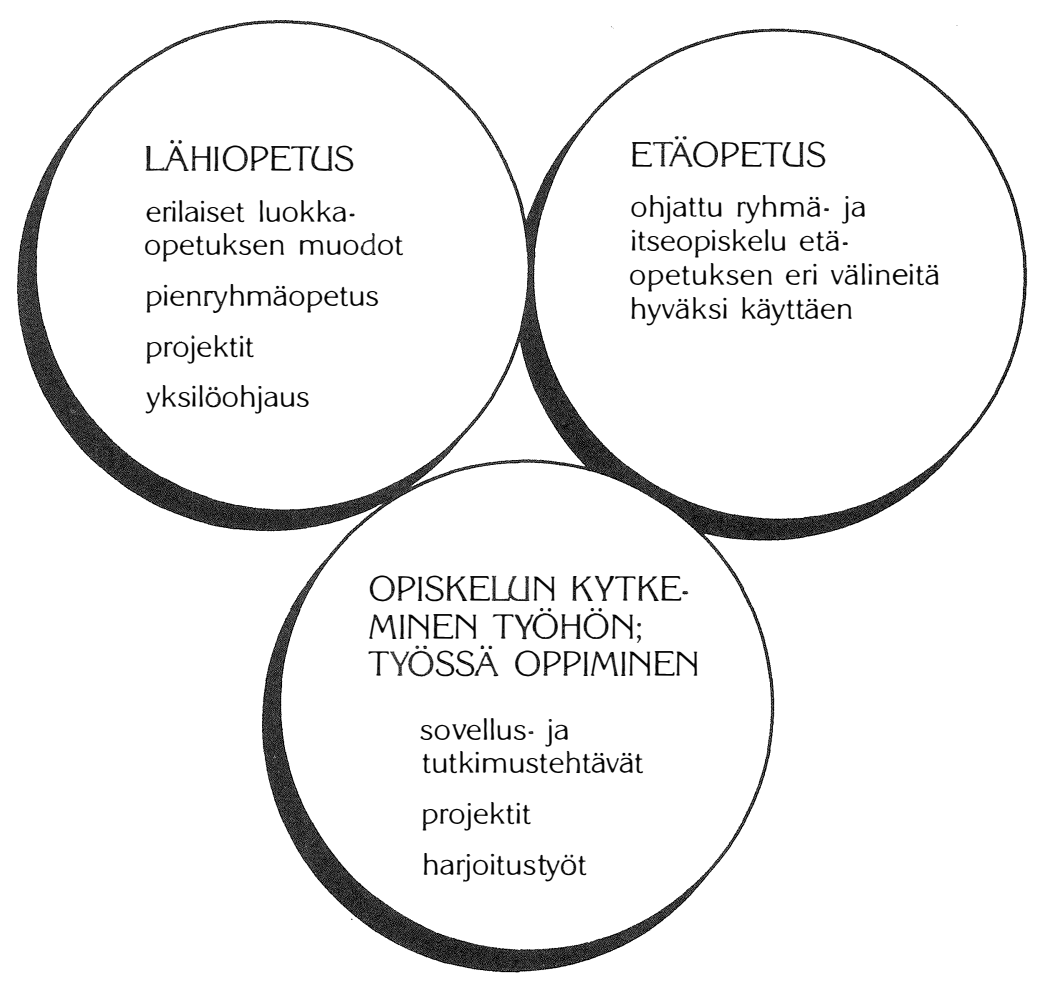

Lähde: Tapio Vaherva_Jorma Ekola: Aikuisten opettamisen taito s. 87. 
Etäopetusmuotoina ovat olleet ryhmäopiskelu ja itseopiskelu; apuna käytettiin välineitä, jotka helpottivat ja monipuolistivat tiedon siirtämistä ja mahdollistivat vuorovaikutuksen. Näistä välineistä ja laitteista saatuihin kokemuksiin palataan kirjoituksessa myöhemmin.

Kolmas elementti opiskelun kytkeminen työhön merkitsi harjoitus- ja soveltamistehtävien etsimistä opiskelijan työympäristöstä. Opettajalla ei ollut ongelmiin valmiita ratkaisuja, vaan opiskelijat etsivät vastauksia oppimateriaaleista ja tietopankeista yhdessä toisten opiskelijoiden ja opettajan kanssa.

\section{Tilat ja laitteet}

Monimuoto-opetus edellyttää erityisjärjestelyjä koulutustilojen, laitteiden ja välineiden osalta. Opiskelijat jaettiin asuinpaikan mukaan lähi- ja etäopetusryhmiin. Lähiopetusryhmä toimi Torniossa instituutin tiloissa ja etäopetusryhmät eri paikkakunnilla jonkin oppilaitoksen tai PTL-Telen tiloissa. Etäopetuksessa oleva opiskelija saattoi joko kuulua alueryhmään tai opiskella yksin kotonaan, jos lähellä ei ollut muita vastuuhenkilökoulutuksen opiskelijoita. Alueryhmät valitsivat keskuudestaan ryhmän vetäjän, jonka tehtävänä oli $\mathrm{mm}$. johtaa ryhmäpalaverit, toimittaa oppimateriaalit muille jäsenille sekä huo. lehtia ryhmän opiskelumotivaation säilymisestä. - Vetäjien tehtävä osoittautui tärkeäksi; he tarvitsevat sen hoitamiseen koulutusta.

Eri paikkakunnilla yksin tai ryhmissä opiskelevat olivat puheyhteydessä toisiinsa ja opettajaan opetuspuhelimen välityksellä. Puhelinluennon pituus vaihteli puolesta puoleentoista tuntiin. Sen aikana opettaja opetti uuden asian ja antoi ryhmätehtävät kyseistä iltaa varten.

Opiskelijoiden kokemukset puhelimen käytöstä ovat voittopuolisesti myönteisiä: keskustelu on ollut vapaata, jopa vapaam. paa kuin luokassa, arvelivat muutamat.

Toisaalta tarvitaan aimo annos omaa aktiivisuutta seurata opetusta ja osallistua keskusteluun silloinkin, kun opettaja ei näe. Opettajalta puhelinopetus edellyttää huolellista suunnittelua. Katsekontaktin puuttumisesta huolimatta on osattava kuunnella ja aktivoida oppilaita. Muutoin saattavat kuulijat yksi toisensa jälkeen sulkea puhelimen ja opettaja huomaa keskustelevansa yksin. Opettajat tottuivat kuitenkin opetuspuhelimen käyttöön nopeasti. Opettaja voi lisäksi hoitaa luennon mistä tahansa, vaikka kotipuhelimestaan. Samoin opiskelijat voivat osallistua koulutukseen esimerkiksi matkoilla ollessaan.

\section{MONIMUIOTO-OPETUKSEN VÄLINEET}

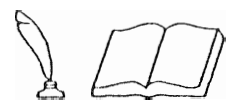

TEKSTI

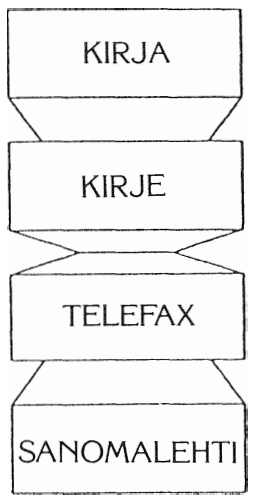

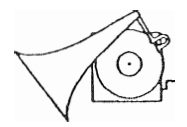

ÄÄNI

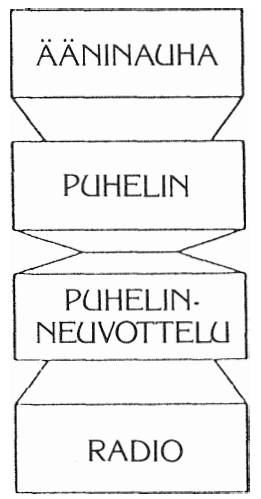

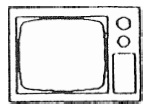

KUVA

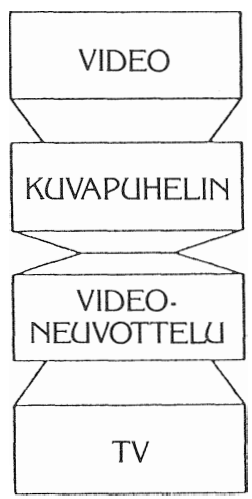

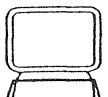

TIETOKONE

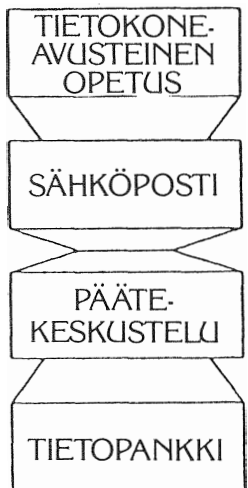


Yhteydenpitoon käytettiin myös telekopiolaitetta. Opettaja saattoi jo päivällä lähettää oppilaille illan luentorungon ja tehtävät. Loppuillasta oppilaat palauttivat ratkaisunsa opettajan tarkastettavaksi.

Jokaisella opiskelijalla oli joko työpaikassaan tai opiskelupisteessään mikrotietokone. Sen avulla he tekivät harjoitustehtäviä ja olivat yhteydessä TeleSampoon ja LT-instituutin MikroVAX-keskustietokoneeseen. Mikrotietokoneet olivat välttämättömiä apuvälineitä tietotekniikan opetuksessa: lisäksi oli tarpeen käyttää myös työpaikan laitteita ja ohjelmistoja, jotta jokainen saattoi soveltaa saa. maansa oppia omaan työhönsä.

Tiedonvälityksessä kokeiltiin päätekeskustelua. Siinä opettaja ja opiskelijat olivat samanaikaisesti tietokonepäätteidensä avulla ns. päätepuhelinkeskustelussa. Opettajan päätteellä näkyi enimmillään kuuden opiskelijan näyttöruudun osa ja opiskelijat näkivät omilla ruuduillaan kaiken opettajan kirjoitta. man tekstin. - Keskustelu onnistui, mutta osoittautui MikroVax-tietokoneelle raskaaksi ja hitaaksi.

Myös päätepostia eli sähköpostia kokeiltiin. Instituutin MikroVax-laitteistossa oli postilaatikko, johon opettaja lähetti materiaalia, harjoitustehtäviä ja koekysymykset. Opiskelijat lähettivät sinne vastauksensa. Sähköpostin avulla toteutettiin toimistoautomaation koe.

Kokeilun aikana ja pian sen jälkeen ovat yleiset sähköpostipalvelut lisääntyneet ja kehittyneet ja niiden merkitys monimuotoopiskelussa lisääntynee. Sähköposti on kirjettä nopeampi ja joustavampi. Se mahdollistaa myös henkilökohtaisen vuorovaikutuksen, mikäli jokaisella opiskelijalla on käytössään oma laite ja postilaatikko.

\section{Videoneuvottelu}

Julkishallinnon ryhmän koulutuksessa kokeiltiin videoneuvottelua. Opiskelijat kokoontuivat seminaaripäiville PTL-Telen Rovaniemen neuvottelustudioon ja luennoitsijat Helsinkiin vastaavaan studioon. Aiheena oli Kuinka sähköpostit ja valtakunnallinen toimistoautomaatio muuttavat lappilaisten työn luonnetta. Kittiläläinen opiskelija kertoi aluksi lappilaisten odotuksista ja tarpeista ja sen jälkeen asiantuntijat esittivät lyhyet alustuksensa. Niiden pohjalta käytiin vilkas keskustelu, jossa kaikki osapuolet saivat uutta tietoa.
Sekä opiskelijat että luennoitsijat pitivät tilaisuutta onnistuneena ja antoisana. Olennaisena pidettiin videoneuvottelun vuorovaikutteisuutta: muutenhan menetelmä ei poikkeaisi television tai videon yksisuuntaisesta tiedonvälityksestä. - Opiskelua varten videoneuvottelutilojen pitää olla riittävän suuria ja niitä tulisi olla muuallakin kuin suurissa kaupungeissa. Tulevaisuudessa voitaneen käyttää kuvapuhelinta "joka kylän videoneuvotteluna". Kokeilun aikana kuvapuhelimet olivat liian kalliita, mutta hinnat ovat laskeneet merkittävästi.

\section{Opiskelun kytkeminen työhön}

Harjoitustöiden aiheet pyrittiin löytämään opiskelijoiden omasta työympäristöstä. Tietotekniikan hyödyntämismahdollisuuksien oivaltaminen edellyttää tietotekniikan soveltamista tuttuihin tehtäviin. Esimerkkinä harjoitustöistä mainittakoon yrityksen tietojärjestelmän hankinnan toteuttaminen. Yrityksessä tehtiin tietojenkäsittelyn kehittämissuunnitelma seinätekniikan avulla. Atk-vastuuhenkilöksi opiskeleva toimi projektin vetäjänä ja työryhmään kuuluivat mm. yrityksen johto ja eri toiminta-alueiden vastaavat.

Tietojärjestelmän hankintaan liittyvän opetusjakson aikana tehtiin tarjouspyynnöt, tarjousvertailut sekä tutustuttiin eri toimittajien tarjoamiin järjestelmiin. Mukana olivat alueryhmän kaikki opiskelijat. Yksikään tarjouksista ei vastannut yrityksen vaatimuksia, eikä hankintaa tehty koulutuksen aikana. Projekti on jatkunut vastuuhenkilön vetämänä ja hankintapäätöskin on nyttemmin tehty.

\section{Oppimateriaalit}

Tietotekniikan av-materiaalista on puutetta. Tietokoneavusteisia ohjelmia, videoita ja äänikasetteja on tarjolla liian vähän. Toisaalta tällaisen materiaalin tekeminen on kallista ja se vanhenee pian.

Kokeiluun liittyen tuotettiin video-ohjelma monimuoto-opetuksesta. Tätä voivat käyttää uudet etäopiskelijat sekä sellaiset oppilaitokset ja yritykset, jotka haluavat käyttää opetuksessaan monimuoto-opetusmenetelmiä.

Sanomalehden käyttöä varten tehtiin opetussarjakuva aiheesta Tietojärjestelmän hankinta. Se julkaistiin pohjoissuomalaisissa sanomalehdissä samassa tahdissa kyseisen opetusjakson kanssa. 
Perusmateriaalina ovat kuitenkin olleet kirjat; niiden lisäksi opettajat laativat runsaasti täydentävää materiaalia.

\section{Mitä maksaa?}

Suurin kustannus koitui tietokoneiden hankinnasta, niiden lunastushinta oli noin 234000 markkaa. Opiskelijoiden telekopiolaitteiden leasingkustannukset olivat 475 $\mathrm{mk} / \mathrm{laite} / \mathrm{kk}$, oppilaitoksen laitteen 900 $\mathrm{mk} / \mathrm{kk}$. Posti- ja puhelinkuluja maksettiin kokeilun aikana hieman yli 100000 markkaa.

Opettajille maksettiin palkka kauppaoppilaitosten voimassa olleen virkaehtosopimuksen mukaisesti. Etäopetuksen ja siihen liittyvän oppimateriaalin suunnittelusta opettajille maksettiin kahdesta pidetystä oppitunnista yhden lisätunnin palkkio. Korvaus ei kuitenkaan ollut riittävä laadukkaan etäopetusmateriaalin suunnittelemiseksi ja valmistamiseksi.

Opiskelijat saivat opintotukea työllisyyskoulutuksesta annettujen säännösten mukaan. Koulutustuki oli opiskelijaa kohden keskimäärin 580 markkaa kuukaudessa. Tuki kattoi seminaaripäivien matka-, majoitusja ruokakuluja sekä matkakuluja alueryhmien kokoontumispaikkoihin.

\section{Opiskelijat}

Kurssiesitteen ja sanomalehti-ilmoituksen perusteella koulutukseen hakeutui 118 henkilöä ympäri Lappia; tiedusteluja tuli läänin ulkopuoleltakin. Koulutukseen pääsi 41 hakijaa. Valintakriteereinä olivat kaikki Laiko-koulutuksen vaatimukset: 25 vuoden ikä, ammatillinen peruskoulutus ja vähintään kahden vuoden työkokemus. Lisäksi edellytettiin motivaatiota koulutuksen loppuunsaattamiseen ja työnantajan suositusta. Hakija ei saanut pyrkiä kurssille pelkästään ohjelmointitaitoaan kartuttamaan, vaan hänellä tuli olla jonkin sovellusalueen tuntemus.

Julkishallinnon ryhmän valinnassa pidettiin vielä silmällä seuraavia näkökohtia: haluttiin, että osa opiskelijoista muodostaa alueryhmiä, osa opiskelee yksin. Eri toimialoilta ja läänin eri puolilta haluttiin tasapuolinen edustus. Koulutukseen pääsyä edisti, jos hakija oli valmis taloudelliseen panostukseen eikä hakijalla ollut muuta mahdollisuutta saada atk-vastuuhenkilökoulutusta.
Yritysryhmään valittiin 21 ja julkishallinnon ryhmään 20 henkilöä. Opiskelijoiden keski-ikä oli 36 vuotta, naisia oli 24 ja miehiä 27. Tyypillinen kurssilainen oli työssä käyvä keski-ikäinen nainen, joka oli suorittanut keskikoulun ja merkonomin tutkinnon. Useimmat olivat hankkineet atk-alan koulutusta, esimerkiksi tietotekniikan perusteista. Lukuunottamatta Kemi-Tornion alueen opiskelijoita kurssilaiset asuivat keskimäärin 152 kilometrin päässä Torniosta.

Yritysryhmä opiskeli aluksi neljänä iltana viikossa neljä tuntia kerrallaan. Tämä osoittautui pian liian rankaksi ja opetusta vähennettiinkin kolmeen iltaan viikossa. Julkishallinnon ryhmä kokoontui alusta alkaen kahtena iltana viikossa, mikä osoittautui sopivaksi.

\section{Miksi koulutukseen?}

Ritva Moilanen on tutkimuksessaan selvitellyt koulutukseen hakeutumiseen vaikuttaneita tekijöitä (Moilanen, Monimuoto-opetuksen soveltuvuus aikuisten täydennyskoulutukseen. Lapin aikuiskoulutuskokeilun raportteja 4/1989).

Opiskelemaan on lähdetty, koska on tunnettu mielenkiintoa opittavien asioiden sisältöä ja niiden käyttömahdollisuuksia kohtaan. Sisällölliset motivaatiotekijät ovat olleet selvästi etusijalla. Myös ulkoisilla motivaatiotekijöillä, esimerkiksi vaihtelunhalulla ja mahdollisuudella edetä uralla on ollut jonkin verran vaikutusta.

Tärkeitä seikkoja olivat myös mahdollisuus opiskella kotipaikkakunnalla työn ohessa ja itsenäisesti omien olosuhteiden mukaisesti. Vain neljällä kurssilaisella olisi ollut mahdollisuus osallistua vastaavaan koulutukseen, jos se olisi järjestetty muualla kuin kotipaikkakunnalla perinteisenä päiväkurssina.

\section{Osallistuminen koulutukseen}

Yritysryhmä kokoontui yhteensä 137 kertaa, joista seminaaripäiviä oli 20. Julkishallinnon ryhmä kokoontui 120 kertaa, joista seminaaripäiviä oli 25. Puhelinneuvotteluun osallistuttiin aktiivisemmin kuin seminaaripäiviin. Syynä oli ilmeisesti se, että seminaarit pidettiin yleensä Torniossa, jonne matkaa saattoi kertyä useita satoja kilometrejä. Puhelinneuvotteluun oli helpompi osallistua. 

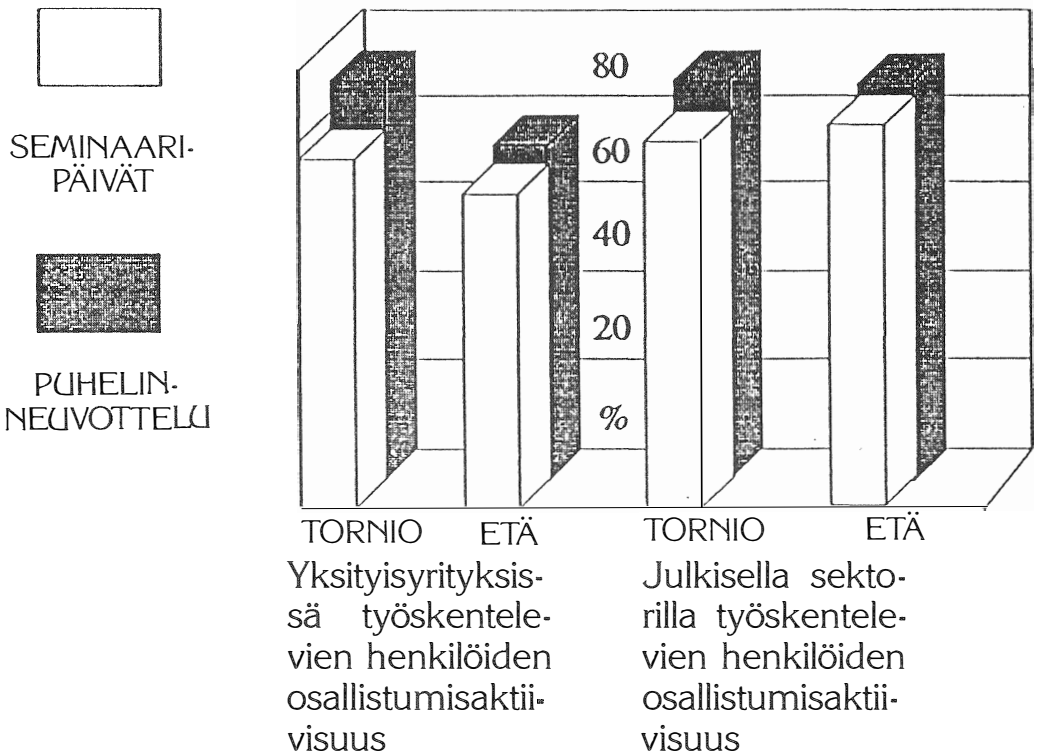

Prosenttiluvut kuvaavat opetukseen osallistumista henkilömäärinä.

Mikäli opiskelija ei voinut osallistua opetukseen, hän sai oppimateriaalin ja tiedot käsitellyistä asioista ryhmän muilta jäseniltä.

Opiskelun keskeytti yhteensä viisi henkilöä. Syynä olivat työkiireet, henkilökohtaiset asiat tai muutto läänin ulkopuolelle.

\section{Arviointia}

Kurssin päätyttyä opiskelijoilta kyseltiin mielipiteitä ja parannusehdotuksia. Ritva Moilasen tutkimuksen mukaan ilmeni seuraavaa:

Opiskelua oli vaikeuttanut selvimmin yksilöllisen ohjauksen vähäisyys ja opiskeluajan puute. Ajan puute selittyy paljolti aikuisopiskelijan elämäntilanteesta: Kaikki kurssilaiset kävivät työssä ja lähes kaikki olivat perheellisiä. Opiskeluryhmät olivat suhteellisen heterogeenisia $\mathrm{mm}$. iän, pohjakoulutuksen ja työkokemuksen suhteen. Tämä selittänee ainakin osittain sen, että yksilöllistä ohjausta olisi saanut olla enemmän.

Lähes puolet opiskelijoista oli harkinnut opiskelun keskeyttämistä; syiksi mainittiin vaikeudet pysyä mukana, turhautuminen, työkiireet tai opetukseen liittyvät tekijät.

Kaikkiaan opiskelijat olivat suhteellisen tyytyväisiä opiskeluun, julkishallinnon ryh- män opiskelijat hiukan tyytyväisempiä kuin yritysryhmän. Ero selittynee osittain sillä, että yritysryhmä oli ensimmäinen kokeiluryhmä ja alussa kaikki oli uutta ja kokemusta puuttui niin suunnittelijoilta kuin opettajilta. kin.

Opetusmenetelmistä ja -välineistä hyviksi koettiin yleensä ne, joissa korostuu opiskelijan ja opettajan vuorovaikutus, esimerkiksi seminaaripäivät ja puhelinneuvottelu.

Opiskelijat toivoivat lisää mikrotietokoneiden käyttöä. Jokaisella olisi pitänyt olla käytössään oma laite. Opettajien tottumattomuus monimuoto- ja aikuisopetukseen aiheutti ongelmia, ajoittain myös tekniikan pettäminen. Opetussuunnitelmaan liittyvistä tekijöistä tulivat esille opetusjaksojen liiallinen teoreettisuus ja niiden huono järjestys tai pinnallinen käsittely.

Opettajien antaman ohjauksen ja palautteen määrässä oli opiskelijoiden mielestä parantamisen varaa. Yksikään vastanneista ei pitänyt saamaansa ohjausta ja palautetta täysin riittävänä. Palaute ei myöskään tullut kyllin nopeasti. Toisaalta noin puolet opiskelijoista piti palautetta motivoivana ja aktivoivana; yli puolet katsoi, että oli helppo saada neuvoja ja ohjausta.

Yleensä kurssin ilmapiiri koettiin miellyttäväksi ja kannustavaksi ja keskusteluihin osal- 
listuminen helpoksi. Kuitenkin yli puolet opiskelijoista ajatteli, etteivät etäopettajat tulleet riittävän tutuiksi. Yhteydenottoa heihin ei silti pidetty kovin vaikeana. Suurin osa opiskelijoista oli kokenut, että heidän toivomuksiaan oli kurssilla otettu huomioon. He eivät tunteneet itseään eristyneiksi opiskelun aikana; vain kaksi yksin opiskellutta opiskelijaa oli jonkin verran eri mieltä.

Parannusehdotuksia kysyttäessä opiskelijat toivoivat opetusjärjestelyiden huolellista suunnittelua. Laitteiden toimiminen ja niiden käyttömahdollisuuksien turvaaminen nähtiin tärkeänä. Opiskelua helpottaisi myös ryhmän homogeenisuus ja runsas käytännön harjoittelu. Opettajien valintaan ja ennakkovalmennukseen tulisi kiinnittää huomiota. Heillä tulisi olla selkeä esitystapa ja mielellään kokemusta etäopetuksesta. Suoraan oppikirjaa seuraavia luentoja pitäisi välttää.

Lähes kaikki opiskelijat ilmoittivat haluavansa myös tulevaisuudessa opiskella monimuoto- ja etäopiskelun avulla. Perusteluina mainittiin taloudelliset syyt ja mahdollisuus opiskella työn ohessa kotipaikkakunnalla.

Opiskelijoiden mielipiteitä selvitettiin kurssin päätöspäivänä myös yhteisessä loppukeskustelussa. Siinä korostuivat myönteisinä seikkoina seuraavat: Monet tunsivat saa. neensa kurssilla runsaasti konkreettista tietoa, jota muualta ei olisi ollut saatavissa. Kurssin laajuus oli ollut myönteinen yllätys. Oppiminen oli ollut monelle helppoa, perheen ja ryhmän tuki oli huomattu tärkeäksi; muutamilla jopa yritys oli elänyt kurssin mukana. Ryhmässä opiskelleet pitivät jäsenten erilaisuutta rikkautena, joskin siitä koitui myös ongelmia.

Kaikkineen opetustapa toimi ja kurssin tavoitteet saavutettiin kurssilaisten mielestä hy. vin. Lähdettiin riittävän alkeellisista lähtökohdista; tärkeinä asiakokonaisuuksina pidettiin mm. tietojärjestelmän hankintaa ja käyttöönottoa sekä toimistoautomaatiota. Parasta oli harjoitustyön tekeminen.

Kehittämistä vaativina seikkoina opiskelijat toivat keskustelussa esiin seuraavaa: Työnantajat pitäisi saada tiiviimmin mukaan. Samalta paikkakunnalta tulisi olla vähintään kaksi opiskelijaa. Kurssin opetussuunnitelmaa arvosteltiin toisaalta laajuuden mutta myös suppeuden ja epäyksilöllisyyden vuoksi. Erityisesti tietokoneiden käyttö vaatii perusteellisen harjoittelun ja varsinkin alussa on yksilöllinen ohjaus tarpeen.

\section{Suosituksia ja päätelmiä}

Useimmat käytetyistä opetusmenetelmistä ovat osoittautuneet käytännössä toimiviksi, mutta menetelmien didaktiikka vaatii vielä paljon kehittelyä. Toisaalta negatiivisetkaan kokemukset eivät välttämättä merkitse, että jokin menetelmä ei sovellu aikuisten monimuoto-opetukseen. Mahdollisuuksia ei vain ole vielä osattu käyttää oikein, opastus on jäänyt puutteelliseksi tai tekniikka on vielä keskeneräistä.

Opiskelijat ja opettajat ovat pitäneet neuvottelupuhelinta välttämättömänä tässä muodossa toteutetun etäopetuksen kannalta. Kustannukset on vain saatava riittävän alhaisiksi esimerkiksi käyttämällä oppilaitoskohtaisia opetuspuhelinnumeroita.

Opiskelun ja opetuksen alkuun tulee kiinnittää erityistä huomiota. Opettajan ja opiskelijoiden on tutustuttava toisiinsa ennen etäopetusjakson alkua. Lisäksi opettajalla tulee olla riittävästi taustatietoa opiskelijoista, heidän työpaikoistaan ja työtehtävistään. Jokainen opiskelija voi laatia kirjallisen esittelyn itsestään ja työstään jaettavaksi muille opiskelijoille ja opettajalle. - Opetusjaksojen alussa on opettajat ja opiskelijat perehdytettävä hyvin käytettäviin opetusmenetelmiin ja uusiin työskentelytapoihin. Ajankäyttö on suunniteltava huolellisesti.

Alueryhmien vetäjille tulee järjestää lisä. opetusta: opiskelun aikana on heidän kanssaan syytä pitää palavereja, joissa käydään läpi ilmenneitä ongelmia ja kehittämismah. dollisuuksia.

Alueryhmillä tulee olla riittävän hyvät ja rauhalliset tilat, välineet ja tietoliikenneyhteydet.

Monimuoto-opetus kehittyy ripeästi. Teollisuusyhteiskunnassa mentiin kouluun ja kursseille, tietoyhteiskunnassa opetus voi tulla kotiin tai työpaikalle. Aikuiskoulutustarpeen lisääntyessä tulee kaikkien opiskelijoiden olla tasa-arvoisia riippumatta työstä, työttömyydestä, perheestä, kotipaikkakunnasta, iästä, peruskoulutuksesta tai mahdollisista sairauksista ja vammoista. Monimuoto. opetuksen avulla voidaan tätä tasa-arvoa parantaa. Sen vuoksi kokemusten vaihto kotimaassa ja laajemminkin on välttämätöntä. Myös kansainvälistä ja ennen kaikkea pohjoismaista yhteistyötä tarvitaan mahdollisim. man paljon. 
Eliisa Hacklin 1990. Turning out EDP Experts through the Implimentation of Multiform Teaching in Lapland.

- This article by Eliisa Hacklin deals with the application of multi-form teaching in Lapland in data processing studies. The central issue in the experiment was to find out how well this type of a course lends itself to be carried out alongside a person's regular job. The experiment was also aimed at providing practical information on the appropria-teness of distance teaching methods. 